\title{
ANALISA PENGELOLAAN MODAL KERJA PADA PERUSAHAAN INDUSTRI SEMEN
}

\author{
Engelwati Gani \\ Jurusan Akuntansi, Fakultas Ekonomi dan Bisnis, Bina Nusantara University \\ Jln. KH Syahdan No 9, Kemanggisan, Palmerah, Jakarta Barat 11480
}

\begin{abstract}
The purpose of this research is to identify financial ratios, to analyse the relation among the financial ratios, and to compare financial ratios of PT Indocement Tunggal Prakarsa, Tbk., PT Semen Gresik (Persero), Tbk., dan PT Holcim Indonesia, Tbk. The research method is qualitative, descriptive research, with the research time dimention using time series. The research depth is using the three industrial cement companies that listed in Indonesia Stock Exchange (BEJ). The gathering data method is by indirect contact like archive data.

Keywords: financial ratios, working capital, cash conversion cycle

ABSTRAK

Tujuan dari penelitian ini adalah menentukan rasio-rasio keuangan, menganalisis hubungan antar rasio keuangan, dan membandingkan rasio keuangan PT Indocement Tunggal Prakarsa Tbk., PT Semen Gresik (Persero) Tbk., dan PT Holcim Indonesia Tbk. Metode penelitian yang digunakan yaitu kualitatif, riset deskriptif, dengan dimensi waktu riset menggunakan time series. Kedalaman riset menggunakan tiga perusahaan industri semen yang terdaftar di Bursa Efek Indonesia. Metode pengumpulan datanya adalah kontak tidak langsung seperti data arsip.
\end{abstract}

Kata kunci: rasio-rasio keuangan, modal kerja, siklus konversi kas 


\section{PENDAHULUAN}

\section{Latar Belakang Penelitian}

Setiap perusahaan selalu membutuhkan dana untuk membiayai kegiatan operasional. Modal kerja merupakan kebutuhan yang sangat vital dalam suatu perusahaan. Modal kerja digunakan untuk membiayai operasional perusahaan seperti membeli bahan baku, membayar bahan baku kepada supplier. Jadi, modal kerja yang dimiliki perusahaan akan menentukan keberhasilan perusahaan dalam menjalankan kegiatan operasional.

Untuk kelancaran operasional perusahaan, maka manajemen harus menentukan dana modal kerja yang digunakan untuk kelangsungan perusahaan. Modal kerja berhubungan erat dengan dana yang digunakan perusahaan untuk kegiatan operasional perusahaan sehari-hari. Karena modal kerja menunjang segala aktivitas perusahaan sehingga diperlukan modal kerja yang cukup untuk melindungi kemungkinan terjadinya krisis keuangan, merencanakan, dan mengawasi rencana perusahaan menjadi rencana keuangan jangka pendek, menilai kecepatan perputaran modal kerja, dan memenuhi kewajiban jangka pendek sesuai jatuh tempo. Dengan menganalisis efisiensi modal kerja dapat diketahui kebijaksanaan operasional yang dilakukan perusahaan sehingga dapat diketahui apakah penggunaannya telah dilakukan dengan efisien.

Modal kerja yang berlebihan akan menunjukkan bahwa dana tidak digunakan seefisien mungkin karena dalam hal ini dana yang seharusnya digunakan untuk memperoleh keuntungan disiasiakan. Untuk menghindari ketidaktepatan modal kerja, maka diterapkan analisis rasio. Dengan adanya analisis rasio tersebut, maka akan diperoleh gambaran tentang keadaan perusahaan, apakah mengalami perkembangan atau tidak. Pengelolaan modal kerja yang efektif merupakan kegiatan yang penting dalam perusahaan. Untuk menganalisa pengelolaan modal kerja suatu perusahaan digunakan analisa laporan keuangan yang bermanfaat bagi pihak-pihak yang berkepentingan.

Karena pentingnya pengelolaan modal kerja suatu perusahaan maka penulis tertarik untuk melakukan penelitian terhadap pengelolaan modal kerja suatu perusahaan. Penelitian dilakukan pada perusahaan go public yang bergerak di bidang industri semen karena perusahaan semen memiliki peranan penting dalam kebutuhan konsumen untuk melakukan pembangunan. Perusahaan industri semen yang diteliti adalah perusahaan yang sudah terdaftar di BEI (Bursa Efek Indonesia) yaitu PT Indocement Tunggal Prakarsa Tbk, PT Semen Gresik (Persero) Tbk, dan PT Holcim Indonesia Tbk sebagai objek penelitian. Penulis memilih ketiga perusahaan semen di Bursa Efek Indonesia karena yang terdaftar di Bursa Efek Indonesia hanya ada tiga perusahaan semen yang listing. Berdasarkan uraian tersebut, peneliti memilih judul "Analisa Pengelolaan Modal Kerja Pada Perusahaan ] Semen.”

\section{Landasan Teori}

\section{Modal Kerja}

\section{Pengertian Modal Kerja}

Pengertian modal kerja dapat dilihat dari beberapa penjelasan. Harahap (2001) mendefinisikan: "Modal kerja adalah aktiva lancar dikurangi utang lancar. Modal kerja juga bisa dianggap sebagai dana yang tersedia untuk diinvestasikan dalam aktiva tidak lancar atau untuk membayar utang tidak lancar” (p. 288). Sutrisno (2001), mendefinisikan: "Modal kerja adalah dana yang diperlukan oleh perusahaan untuk memenuhi kebutuhan operasional sehari-hari, seperti pembelian bahan baku, pembayaran upah buruh, membayar utang dan pembayaran lainnya” (p. 42). Sementara, Gitasudarmo 
(2002), mendefinisikan: "Modal kerja adalah kekayaan atau aktiva yang diperlukan oleh perusahaan untuk menyelenggarakan kegiatan sehari-hari yang selalu berputar dalam periode tertentu. Modal yang dimaksud adalah modal kerja netto (aktiva lancar) perusahaan” (p. 35). Kasmir (2010), mendefinisikan sebagai berikut:

"Modal kerja adalah modal yang digunakan untuk membiayai operasional perusahaan sehari-hari, terutama yang memiliki jangka waktu pendek” (p. 210).

Berdasarkan pengertian diatas maka dapat disimpulkan bahwa modal kerja adalah modal yang diperlukan perusahaan untuk menjalankan kegiatan operasional sehari-hari dalam jangka waktu yang pendek.

\section{Konsep Modal Kerja}

Menurut Sutrisno (2000), ada tiga macam konsep modal kerja yang biasa digunakan untuk analisis, yaitu: modal kerja kuantitatif, kualitatif, dan fungsional. Modal kerja kuantitatif menitikberatkan pada segi kuantitas dana yang tertanam dalam aktiva yang masa perputarannya kurang dari satu tahun. Modal kerja menurut konsep ini adalah keseluruhan elemen aktiva lancar. Oleh karena semua elemen aktiva lancar diperhitungkan sebagai modal kerja tanpa memperhatikan kewajiban-kewajiban jangka pendeknya, maka modal kerja ini sering disebut modal kerja bruto atau gross working capital.

Pada modal kerja kualitatif, modal kerja bukan semua aktiva lancar tetapi telah mempertimbangkan kewajiban-kewajiban yang segera harus dibayar. Dengan demikian dana yang digunakan benar-benar khusus digunakan untuk membiayai operasi perusahaan sehari-hari tanpa khawatir terganggu oleh pembayaran-pembayaran hutang yang segera jatuh tempo. Sementara itu, modal kerja fungsional lebih menitikberatkan pada fungsi dana dalam menghasilkan penghasilan langsung atau current income. Dan pengertian modal kerja menurut konsep ini adalah dana yang digunakan oleh perusahaan untuk menghasilkan current income sesuai dengan tujuan didirikannya perusahaan pada satu periode tertentu.

\section{Kebutuhan Modal Kerja}

Menurut Kasmir (2010), ada beberpa faktor yang dapat mempengaruhi modal kerja antara lain tergantung dari: (1) jenis perusahaan: ada 2 jenis perusahaan yaitu perusahaan yang bergerak di bidang jasa dan non jasa. Kebutuhan modal di perusahaan non jasa lebih besar dari pada perusahaan jasa; (2) syarat kredit, yang pembayarannya dilakukan dengan cara mencicil. Untuk meningkatkan penjualan dapat dilakukan dengan memberikan penjualan secara kredit; (3) waktu produksi, makin lama waktu yang digunakan untuk memproduksi barang, maka makin besar modal kerja yang dibutuhkan. Sebaliknya, makin pendek waktu yang dibutuhkan untuk memproduksi modal kerja, maka makin kecil modal kerja yang dibutuhkan; (4) tingkat perputaran sediaan, makin kecil atau rendah tingkat perputaran, maka kebutuhan modal kerja makin tinggi. Sebaliknya, makin besar tingkat perputaran, maka kebutuhan modal kerja makin rendah.

\section{METODOLOGI PENELITIAN}

\section{Objek Penelitian}

Dalam penelitian ini dilakukan penelitian pada perusahan industri semen yang terdaftar di Bursa Efek Indonesia (BEI). Ada tiga emiten perusahaan yang bergerak pada industri semen yang terdaftar di BEI (Bursa Efek Indonesia) yaitu: Indocement Tunggal Prakarsa Tbk., Holcim Indonesia Tbk., dan Semen Gresik (Persero) Tbk. Objek penelitian yang akan diteliti adalah laporan keuangan 
dari ketiga emiten perusahaan industri semen yang terdaftar di BEI (Bursa Efek Indonesia) periode 2006-2008. Tempat penelitian adalah perusahaan yang terdaftar di Bursa Efek Indonesia (BEI) sehingga mudah untuk memperoleh data-data yang diperlukan untuk mendukung dalam penelitian ini.

\section{HASIL DAN PEMBAHASAN}

\section{Analisis Rasio-Rasio Keuangan}

\section{PT Indocement Tunggal Prakarsa}

Tabel 1 Rasio - Rasio Keuangan PT Indocement Tunggal Prakarsa Tbk

\begin{tabular}{llll}
\hline \multicolumn{1}{c}{ Financial Ratio } & $\mathbf{2 0 0 6}$ & $\mathbf{2 0 0 7}$ & $\mathbf{2 0 0 8}$ \\
\hline Rasio lancar & $214,45 \%$ & $288,64 \%$ & $178,57 \%$ \\
Rasio cepat & $97,08 \%$ & $160,76 \%$ & $100,62 \%$ \\
Rasio kas & $5,50 \%$ & $39,51 \%$ & $40,65 \%$ \\
Rasio perputaran piutang & $10,25 \mathrm{kali}$ & $10,36 \mathrm{kali}$ & $11,38 \mathrm{kali}$ \\
Rasio rata - rata penagihan piutang & $35 \mathrm{hari}$ & $34 \mathrm{hari}$ & 31 hari \\
Rasio perputaran sediaan & $4,38 \mathrm{kali}$ & $4,68 \mathrm{kali}$ & $5 \mathrm{kali}$ \\
Rasio rata - rata penagihan sediaan & 84 hari & 77 hari & 79 hari \\
Rasio perputaran modal kerja & $6,8 \mathrm{kali}$ & $4,98 \mathrm{kali}$ & $6,40 \mathrm{kali}$ \\
Rasio perputaran aktiva tetap & $0,82 \mathrm{kali}$ & $0,96 \mathrm{kali}$ & $1,29 \mathrm{kali}$ \\
Rasio perputaran total asset & $0,66 \mathrm{kali}$ & $0,75 \mathrm{kali}$ & $0,92 \mathrm{kali}$ \\
Rasio perputaran modal kerja bersih & $6,80 \mathrm{kali}$ & $4,98 \mathrm{kali}$ & $6,4 \mathrm{kali}$ \\
Rasio hutang & $37,15 \%$ & $31,33 \%$ & $24,69 \%$ \\
Margin laba atas penjualan & $5,11 \%$ & $7,46 \%$ & $11,84 \%$ \\
Tingkat pengembalian atas total aktiva & $6,18 \%$ & $9,76 \%$ & $15,47 \%$ \\
Tingkat pengembalian atas ekuitas & $9,83 \%$ & $14,20 \%$ & $20,54 \%$ \\
Siklus Konversi Kas & 79 hari & 71 hari & 64 hari \\
Modal Kerja & & & \\
\hline
\end{tabular}

Berdasarkan tabel diatas menunjukkan pada tahun 2006-2008, rasio lancar mengalami peningkatan sebesar 214,45\% pada tahun 2006 menjadi 288,64\% pada tahun 2007, dan mengalami penurunan menjadi 178,57\% pada tahun 2008 disebabkan oleh peningkatan hutang yang signifikan pada tahun 2008. Walaupun mengalami penurunan, perusahaan masih mampu membayar hutang jangka pendeknya. Untuk rasio cepat mengalami peningkatan sebesar 97,08\% pada tahun 2006 menjadi 160,76\% pada tahun 2007 dan mengalami penurunan menjadi 100,62\%. Hal ini menunjukkan bahwa perusahaan dalam keadaan likuid pada rasio lancar dan rasio cepat. Selain itu, rasio kas mengalami peningkatan yang signifikan sebesar 5,50\% pada tahun 2006 menjadi 39,51\% pada tahun 2007 dan pada tahun 2008 meningkat menjadi 40,65\% disebabkan adanya peningkatan kas.

Untuk rasio perputaran piutang mengalami peningkatan 10,25 kali pada tahun 2006 menjadi 10,36 kali pada tahun 2007 dan mengalami peningkatan menjadi 11,38 kali pada tahun 2008 dengan rasio rata - rata penagihan piutang adalah 35 hari pada tahun 2006, 34 hari pada tahun 2007, dan 31 hari pada tahun 2008, hal ini menunjukkan terjadi peningkatan penjualan kredit kepada konsumen dengan jangka waktu penagihan piutang yang menurun. Untuk perputaran persediaan meningkat sebanyak 4,38 kali pada tahun 2006 menjadi 4,68 kali pada tahun 2007 dan pada tahun 2008 menjadi 5 kali dengan rasio rata-rata penagihan sediaan yaitu 84 hari pada tahun 2006, 77 hari pada tahun 2007, dan 79 hari pada tahun 2008, hal ini menunjukkan bahwa dana yang diinvestasikan pada persediaan kurang efektif menghasilkan laba karena perusahaan menyimpan stok yang banyak. 
Untuk perputaran modal kerja bersih mengalami penurunan sebanyak 6,80 kali pada tahun 2006 menjadi 4,98 kali pada tahun 2007 dan pada tahun 2008 menjadi 6,40 kali. Hal ini menunjukkan bahwa perputaran modal kerja bersih selalu positif sehingga dapat dikatakan bahwa perusahaan ini memiliki tingkat hutang yang rendah untuk membiayai kegiatan usahanya. Selain itu, tingkat hutang mengalami penurunan sebesar 37,15\% pada tahun 2006 menjadi 31,33\% pada tahun 2007, dan mengalami penurunan menjadi 24,69\% pada tahun 2008. Penurunan hutang tersebut karena penurunan total hutang yang disebabkan oleh penurunan hutang dividen, hutang bank dan lembaga keuangan. Dengan siklus konversi kas selama 79 hari pada tahun 2006 menjadi 71 hari pada tahun 2007 dan menjadi 64 hari pada tahun 2008, hal ini menunjukkan semakin pendek siklus konversi kas maka akan semakin baik karena semakin sedikit kas yang digunakan untuk membiayai aktiva dan semakin efektif suatu perusahaan dalam menjalankan perputaran hutang perusahaan tersebut. Selain itu, rasio perputaran modal kerja mengalami penurunan sebanyak 6,8 kali pada tahun 2006 menjadi 4,98 kali pada tahun 2007, dan mengalami peningkatan juga sebanyak 6,40 kali pada tahun 2008, hal ini menunjukkan semakin tinggi tingkat perputaran modal kerja maka semakin cepat dana yang diinvestasikan dalam modal kerja kembali menjadi kas, sehingga keuntungan perusahaan dapat lebih cepat diterima.

Perputaran aktiva tetap mengalami peningkatan sebanyak 0,82 kali pada tahun 2006 menjadi 0,96 kali pada tahun 2007 dan mengalami peningkatan juga menjadi 1,29 kali, hal ini menunjukkan peningkatan tingkat efektivitas penggunaan aktiva tetap dalam mendukung kegiatan penjualan. Untuk perputaran total aktiva mengalami peningkatan sebanyak 0,66 kali pada tahun 2006 menjadi 0,75 pada tahun 2007, dan mengalami peningkatan menjadi 0,92 kali pada tahun 2008, hal ini menunjukkan terjadi peningkatan total aktiva karena disebabkan oleh peningkatan tingkat perputaran piutang dan aktiva tetap. Untuk rasio margin laba atas penjualan mengalami peningkatan sebesar $5,11 \%$ pada tahun 2006 menjadi 7,46\% pada tahun 2007, dan mengalami peningkatan juga menjadi 11,84\% pada tahun 2008. Hal ini menunjukkan bahwa kinerja dalam menghasilkan margin laba atas penjualan sangat baik. Selain itu, tingkat pengembalian atas total aktiva yang mengalami peningkatan sebesar 6,18\% pada tahun 2006 menjadi 9,76\% pada tahun 2007, dan mengalami peningkatan juga menjadi 15,47\%, hal ini disebabkan oleh peningkatan perputaran total aktiva dan margin laba atas penjualan. Sedangkan untuk tingkat pengembalian atas ekuitas mengalami peningkatan sebesar 9,83\% pada tahun 2006 menjadi 14,20\% pada tahun 2007, dan mengalami peningkatan juga menjadi 20,54\% pada tahun 2008. Hal ini menunjukkan bahwa profitabilitas perusahaan mengalami peningkatan dalam pengembalian modal.

\section{PT Semen Gresik (Persero) Tbk}

Tabel 2 Rasio-Rasio Keuangan PT Semen Gresik (PERSERO) Tbk

\begin{tabular}{|l|l|l|l|}
\hline \multicolumn{1}{|c|}{ Financial Ratio } & \multicolumn{1}{|c|}{$\mathbf{2 0 0 6}$} & \multicolumn{1}{c|}{$\mathbf{2 0 0 7}$} & \multicolumn{1}{c|}{$\mathbf{2 0 0 8}$} \\
\hline Rasio lancar & $284,45 \%$ & $364,34 \%$ & $338,58 \%$ \\
Rasio cepat & $214,19 \%$ & $291,87 \%$ & $263,03 \%$ \\
Rasio kas & $132,09 \%$ & $203,29 \%$ & $183,37 \%$ \\
Rasio perputaran piutang & $7,90 \mathrm{kali}$ & $8,50 \mathrm{kali}$ & $9,23 \mathrm{kali}$ \\
Rasio rata - rata penagihan piutang & 46 hari & 42 hari & 39 hari \\
Rasio perputaran sediaan & $5,26 \mathrm{kali}$ & $5,40 \mathrm{kali}$ & $5,22 \mathrm{kali}$ \\
Rasio rata - rata penagihan sediaan & 68 hari & 67 hari & 69 hari \\
Rasio perputaran modal kerja & $3,24 \mathrm{kali}$ & $2,51 \mathrm{kali}$ & $2,45 \mathrm{kali}$ \\
Rasio perputaran aktiva tetap & $2,76 \mathrm{kali}$ & $3,07 \mathrm{kali}$ & $3,82 \mathrm{kali}$ \\
Rasio perputaran total asset & $1,16 \mathrm{kali}$ & $1,20 \mathrm{kali}$ & $1,28 \mathrm{kali}$ \\
Rasio perputaran modal kerja bersih & $3,24 \mathrm{kali}$ & $2,51 \mathrm{kali}$ & $2,45 \mathrm{kali}$ \\
Rasio hutang & $25,55 \%$ & $21,09 \%$ & $22,91 \%$ \\
Margin laba atas penjualan & $8,58 \%$ & $10,51 \%$ & $12,10 \%$ \\
Tingkat pengembalian atas total aktiva & $17,28 \%$ & $20,85 \%$ & $23,80 \%$ \\
Tingkat pengembalian atas ekuitas & $23,56 \%$ & $26,79 \%$ & $31,27 \%$ \\
Siklus Konversi Kas & $58 \mathrm{hari}$ & 50 hari & 44 hari \\
Modal Kerja & 2.693 .180 .103 & 3.822 .037 .385 & 4.991 .322 .216 \\
\hline
\end{tabular}


Berdasarkan tabel diatas menunjukkan pada tahun 2006-2008, rasio lancar mengalami peningkatan sebesar 284,45\% pada tahun 2006 menjadi 363,34\% pada tahun 2007, dan mengalami penurunan menjadi 338,58\% pada tahun 2008 disebabkan oleh peningkatan hutang yang signifikan pada tahun 2008. Walaupun mengalami penurunan, perusahaan masih mampu membayar hutang jangka pendeknya. Untuk rasio cepat mengalami peningkatan sebesar 214,19\% pada tahun 2006 menjadi 291,87\% pada tahun 2007 dan mengalami penurunan menjadi 263,03\%. Hal ini menunjukkan bahwa perusahaan dalam keadaan likuid pada rasio lancar dan rasio cepat. Selain itu, rasio kas mengalami peningkatan sebesar 132,09\% pada tahun 2006 menjadi 203,29\% pada tahun 2007 dan pada tahun 2008 menurun menjadi 183,37\% disebabkan oleh peningkatan hutang lancar.

Untuk rasio perputaran piutang mengalami peningkatan sebanyak 7,90 kali pada tahun 2006 menjadi 8,50 kali pada tahun 2007 dan menjadi 9,23 kali pada tahun 2008 dengan rasio rata - rata penagihan piutang adalah 46 hari pada tahun 2006, 42 hari pada tahun 2007, dan 39 hari pada tahun 2008, hal ini menunjukkan terjadi peningkatan penjualan kredit kepada konsumen dengan jangka waktu penagihan piutang yang lebih baik dibandingkan dengan tahun - tahun sebelumnya. Untuk perputaran persediaan meningkat sebanyak 5,26 kali pada tahun 2006 menjadi 5,40 kali pada tahun 2007 dan pada tahun 2008 mengalami penurunan menjadi 5,22 kali dengan rasio rata - rata penagihan sediaan yaitu 68 hari pada tahun 2006, 67 hari pada tahun 2007, dan 69 hari pada tahun 2008, hal ini menunjukkan bahwa dana yang diinvestasikan pada persediaan kurang efektif menghasilkan laba karena perusahaan menyimpan stok yang berlebihan. Untuk perputaran modal kerja bersih mengalami penurunan sebanyak 3,24 kali pada tahun 2006 menjadi 2,51 kali pada tahun 2007 dan mengalami penurunan menjadi 2,45 kali pada tahun 2008. Hal ini menujukkan bahwa perputaran modal kerja bersih selalu positif sehingga dapat dikatakan bahwa perusahaan ini memiliki tingkat hutang yang rendah untuk membiayai kegiatan usahanya. Selain itu, tingkat hutang mengalami penurunan sebesar 25,55\% pada tahun 2006 menjadi 21,09\% pada tahun 2007, disebabkan oleh pelunasan pinjaman dari pemerintah Republik Indonesia yang meliputi hutang pokok, bunga dan denda serta penurunan kewajiban imbalan kerja sebagai akibat dilakukannya penyelesaian kewajiban masa lalu atas program Masa Persiapan Pensiun. Sedangkan tingkat hutang mengalami peningkatan menjadi 22,91\% pada tahun 2008.

Dengan siklus konversi kas selama 58 hari pada tahun 2006 menjadi 50 hari pada tahun 2007 dan menjadi 44 hari pada tahun 2008, hal ini menunjukkan semakin pendek siklus konversi kas maka akan semakin baik karena semakin sedikit kas yang digunakan untuk membiayai aktiva dan semakin efektif suatu perusahaan dalam menjalankan perputaran hutang perusahaan tersebut. Selain itu, rasio perputaran modal kerja mengalami penurunan sebanyak 3,24 kali pada tahun 2006 menjadi 2,51 kali pada tahun 2007, dan menjadi 2,45 kali pada tahun 2008, hal ini menunjukkan semakin rendah tingkat perputaran modal kerja maka semakin lama dana yang diinvestasikan dalam modal kerja kembali menjadi kas. Perputaran aktiva tetap mengalami peningkatan sebanyak 2,76 kali pada tahun 2006 menjadi 3,07 kali pada tahun 2007 dan mengalami peningkatan juga menjadi 3,82 kali, hal ini menunjukkan peningkatan tingkat efektivitas penggunaan aktiva tetap dalam mendukung kegiatan penjualan. Untuk perputaran total aktiva mengalami peningkatan sebanyak 1,16 kali pada tahun 2006 menjadi 1,20 pada tahun 2007, dan mengalami peningkatan menjadi 1,28 kali pada tahun 2008, hal ini menunjukkan terjadi peningkatan total aktiva karena disebabkan oleh peningkatan tingkat perputaran piutang dan aktiva tetap.

Untuk rasio margin laba atas penjualan mengalami peningkatan sebesar 8,58\% pada tahun 2006 menjadi 10,51\% pada tahun 2007, dan mengalami peningkatan juga menjadi 12,10\% pada tahun 2008. Hal ini menunjukkan bahwa kinerja dalam menghasilkan margin laba atas penjualan sangat baik. Selain itu, tingkat pengembalian atas total aktiva yang mengalami peningkatan sebesar $17,28 \%$ pada tahun 2006 menjadi 20,85\% pada tahun 2007, dan menjadi 23,80\% pada tahun 2008, hal ini disebabkan oleh peningkatan perputaran total aktiva dan margin laba atas penjualan. Sedangkan untuk tingkat pengembalian atas ekuitas mengalami peningkatan sebesar 23,56\% pada tahun 2006 menjadi 
26,79\% pada tahun 2007, dan mengalami peningkatan juga menjadi 31,27\% pada tahun 2008. Hal ini menunjukkan bahwa profitabilitas perusahaan mengalami peningkatan dalam pengembalian modal.

\section{PT Holcim Indonesia Tbk}

Tabel 3 Rasio-Rasio Keuangan PT Holcim Indonesia Tbk

\begin{tabular}{llll}
\hline \multicolumn{1}{c}{ Financial Ratio } & $\mathbf{2 0 0 6}$ & $\mathbf{2 0 0 7}$ & $\mathbf{2 0 0 8}$ \\
\hline Rasio lancar & $113,06 \%$ & $114,93 \%$ & $92,84 \%$ \\
Rasio cepat & $86,59 \%$ & $86,84 \%$ & $69,78 \%$ \\
Rasio kas & $37,39 \%$ & $37,36 \%$ & $33,53 \%$ \\
Rasio perputaran piutang & $6,55 \mathrm{kali}$ & $7 \mathrm{kali}$ & $7 \mathrm{kali}$ \\
Rasio rata - rata penagihan piutang & 55 hari & 51 hari & 51 hari \\
Rasio perputaran sediaan & $5,53 \mathrm{kali}$ & $5,84 \mathrm{kali}$ & $5,63 \mathrm{kali}$ \\
Rasio rata - rata penagihan sediaan & 65 hari & 62 hari & 64 hari \\
Rasio perputaran modal kerja & 21,29 kali & 20,08 kali & $(32,63)$ kali \\
Rasio perputaran aktiva tetap & 1 kali & 1,11 kali & 1,05 kali \\
Rasio perputaran total asset & 0,54 kali & 0,58 kali & 0,54 kali \\
Rasio perputaran modal kerja bersih & 21,29 kali & 20,08 kali & $(32,63)$ kali \\
Rasio hutang & $58,11 \%$ & $54,48 \%$ & $60,23 \%$ \\
Margin laba atas penjualan & $11,34 \%$ & $16,80 \%$ & $8,85 \%$ \\
Tingkat pengembalian atas total aktiva & $6,08 \%$ & $9,43 \%$ & $4,93 \%$ \\
Tingkat pengembalian atas ekuitas & $14,52 \%$ & $20,71 \%$ & $12,38 \%$ \\
Siklus Konversi Kas & 17 hari & 13 hari & 10 hari \\
Modal Kerja & 1.126 & 1.347 & $(771)$ \\
\hline
\end{tabular}

Berdasarkan tabel diatas menunjukkan pada tahun 2006-2008, rasio lancar mengalami peningkatan sebesar 113,06\% pada tahun 2006 menjadi 114,93\% pada tahun 2007, dan mengalami penurunan menjadi 92,84\% pada tahun 2008 disebabkan oleh peningkatan hutang. Untuk rasio cepat mengalami peningkatan sebesar 86,59\% pada tahun 2006 menjadi 86,84\% pada tahun 2007 dan mengalami penurunan menjadi $69,78 \%$. Hal ini menunjukkan bahwa perusahaan dalam keadaan illikuid pada rasio lancar dan rasio cepat. Selain itu, rasio kas mengalami penurunan sebesar 37,39\% pada tahun 2006 menjadi 37,36\% pada tahun 2007 dan pada tahun 2008 menurun menjadi 33,53\% disebabkan oleh peningkatan hutang lancar.

Untuk rasio perputaran piutang mengalami peningkatan sebanyak 6,55 kali pada tahun 2006 menjadi 7 kali pada tahun 2007 dan tahun 2008 dengan rasio rata - rata penagihan piutang adalah 55 hari pada tahun 2006, 51 hari pada tahun 2007 dan tahun 2008, hal ini menunjukkan bahwa terjadi peningkatan penjualan dengan jangka waktu penagihan yang lebih cepat dari tahun - tahun sebelumnya. Untuk perputaran persediaan meningkat sebanyak 5,53 kali pada tahun 2006 menjadi 5,84 kali pada tahun 2007 dan mengalami penurunan menjadi 5,63 kali pada tahun 2008 dengan rasio rata-rata penagihan sediaan yaitu 65 hari pada tahun 2006, 62 hari pada tahun 2007, dan 64 hari pada tahun 2008, hal ini menunjukkan bahwa dana yang diinvestasikan pada persediaan kurang efektif menghasilkan laba.

Untuk perputaran modal kerja bersih mengalami penurunan sebanyak 21,29 kali pada tahun 2006 menjadi 20,08 kali pada tahun 2007 dan mengalami penurunan menjadi $(32,63)$ kali pada tahun 2008. Hal ini menujukkan bahwa perputaran modal kerja bersih negatif sehingga dapat dikatakan bahwa perusahaan ini memiliki tingkat hutang yang tinggi untuk membiayai kegiatan usahanya. Selain itu, tingkat hutang mengalami penurunan sebesar 58,11\% pada tahun 2006 menjadi 54,48\% pada tahun 2007, disebabkan oleh kewajiban pajak tangguhan, ketentuan jangka panjang. Sedangkan tingkat hutang mengalami peningkatan menjadi 60,23\% pada tahun 2008. 
Dengan siklus konversi kas selama 17 hari pada tahun 2006 menjadi 13 hari pada tahun 2007 dan menjadi 10 hari pada tahun 2008, hal ini menunjukkan semakin pendek siklus konversi kas maka akan semakin baik karena semakin sedikit kas yang digunakan untuk membiayai aktiva dan semakin efektif suatu perusahaan dalam menjalankan perputaran hutang perusahaan tersebut. Untuk rasio perputaran modal kerja mengalami penurunan sebanyak 21,29 kali pada tahun 2006 menjadi 20,08 kali pada tahun 2007, dan menjadi $(11,88)$ kali pada tahun 2008, hal ini menunjukkan semakin rendah tingkat perputaran modal kerja maka semakin lama dana yang diinvestasikan dalam modal kerja kembali menjadi kas. Rasio perputaran aktiva tetap mengalami peningkatan sebanyak 1 kali pada tahun 2006 menjadi 1,11 kali pada tahun 2007 dan mengalami penurunan menjadi 1,05 kali pada tahun 2008, hal ini menunjukkan penurunan tingkat efektivitas penggunaan aktiva tetap dalam mendukung kegiatan penjualan. Untuk rasio perputaran total aktiva mengalami peningkatan sebanyak 0,54 kali pada tahun 2006 menjadi 0,58 kali pada tahun 2007, dan mengalami penurunan menjadi 0,54 kali pada tahun 2008, hal ini disebabkan oleh penurunan tingkat perputaran aktiva tetap.

Untuk rasio margin laba atas penjualan mengalami peningkatan sebesar 11,34\% pada tahun 2006 menjadi 16,80\% pada tahun 2007, dan mengalami penurunan menjadi 8,85\% pada tahun 2008 . Hal ini menunjukkan bahwa kinerja dalam menghasilkan margin laba atas penjualan kurang baik. Selain itu, tingkat pengembalian atas total aktiva yang mengalami peningkatan sebesar $6,08 \%$ pada tahun 2006 menjadi 9,43\% pada tahun 2007, dan mengalami penurunan menjadi 4,93\%, hal ini disebabkan oleh penurunan perputaran total aktiva dan margin laba atas penjualan. Sedangkan untuk tingkat pengembalian atas ekuitas mengalami peningkatan sebesar 14,52\% pada tahun 2006 menjadi $20,71 \%$ pada tahun 2007, dan mengalami penurunan menjadi $12,38 \%$ pada tahun 2008 . Hal ini menunjukkan bahwa profitabilitas perusahaan mengalami penurunan dalam pengembalian modal.

\section{Perbandingan Rasio Modal Kerja}

\section{Perbandingan Rasio Modal Kerja Tiga Perusahaan Semen Tahun 2006}

Tabel 4 Rasio-Rasio Keuangan Tiga Perusahaan Semen Tahun 2006

\begin{tabular}{llll}
\hline \multicolumn{1}{c}{ Financial Ratio 2006 } & \multicolumn{1}{c}{$\begin{array}{c}\text { PT Indocement } \\
\text { Tunggal } \\
\text { Prakarsa Tbk }\end{array}$} & PT Semen Gresik & $\begin{array}{c}\text { PT Holcim } \\
\text { Indonesia } \\
\text { Tbk }\end{array}$ \\
\hline Rasio lancar & $214,45 \%$ & $284,45 \%$ & $113,06 \%$ \\
Rasio cepat & $97,08 \%$ & $214,19 \%$ & $86,59 \%$ \\
Rasio kas & $5,50 \%$ & $132,09 \%$ & $37,39 \%$ \\
Rasio perputaran piutang & $10,25 \mathrm{kali}$ & $7,90 \mathrm{kali}$ & $6,55 \mathrm{kali}$ \\
Rasio rata - rata penagihan piutang & $35 \mathrm{hari}$ & $46 \mathrm{hari}$ & 55 hari \\
Rasio perputaran sediaan & $4,38 \mathrm{kali}$ & $5,26 \mathrm{kali}$ & $5,53 \mathrm{kali}$ \\
Rasio rata - rata penagihan sediaan & $84 \mathrm{hari}$ & $68 \mathrm{hari}$ & 65 hari \\
Rasio perputaran modal kerja & $6,8 \mathrm{kali}$ & $3,24 \mathrm{kali}$ & $21,29 \mathrm{kali}$ \\
Rasio perputaran aktiva tetap & $0,82 \mathrm{kali}$ & $2,76 \mathrm{kali}$ & $1 \mathrm{kali}$ \\
Rasio perputaran total asset & $0,66 \mathrm{kali}$ & $1,16 \mathrm{kali}$ & $0,54 \mathrm{kali}$ \\
Rasio perputaran modal kerja bersih & $6,80 \mathrm{kali}$ & $3,24 \mathrm{kali}$ & $21,29 \mathrm{kali}$ \\
Rasio hutang & $37,15 \%$ & $25,55 \%$ & $58,11 \%$ \\
Margin laba atas penjualan & $5,11 \%$ & $8,58 \%$ & $11,34 \%$ \\
Tingkat pengembalian atas total aktiva & $6,18 \%$ & $17,28 \%$ & $6,08 \%$ \\
Tingkat pengembalian atas ekuitas & $9,83 \%$ & $23,56 \%$ & $14,52 \%$ \\
Siklus Konversi Kas & 79 hari & $58 \mathrm{hari}$ & $17 \mathrm{hari}$ \\
Modal Kerja & $929,522,396,443$ & $2,693,180,103$ & 1.126 \\
\hline
\end{tabular}


Dari ketiga perusahaan semen tersebut menunjukkan bahwa PT Semen Gresik (Persero) Tbk memiliki rasio lancar paling tinggi dibandingkan dengan PT Indocement Tunggal Prakarsa Tbk dan PT Holcim Indonesia Tbk. Akan tetapi, ketiga perusahaan semen mampu untuk membayar hutang jangka pendek, karena rasio lancar di atas 100\%. Untuk rasio cepat, PT Semen Gresik (Persero) Tbk memiliki rasio cepat paling tinggi. Hal ini menunjukkan PT Semen Gresik (Persero) Tbk dalam keadaan likuid. Selain itu, PT Semen Gresik (Persero) Tbk memiliki rasio kas yang paling tinggi, hal ini menunjukkan bahwa jumlah uang tunai yang tersedia semakin besar, sehingga pada saat jatuh tempo pelunasan hutang tidak mengalami kesulitan. PT Indocement Tunggal Prakarsa Tbk memiliki rasio perputaran piutang yang paling tinggi dibandingkan dengan PT Semen Gresik (Persero) Tbk dan PT Holcim Indonesia Tbk, hal ini menunjukkan bahwa PT Indocement Tunggal Prakarsa Tbk memiliki penjualan paling tinggi. Selain itu, PT Indocement Tunggal Prakarsa Tbk juga memiliki ratarata penagihan piutang yang paling singkat.

Untuk rasio perputaran sediaan, PT Holcim Indonesia Tbk paling tinggi, hal ini menunjukkan bahwa dana yang diinvestasikan pada persediaan efektif menghasilkan laba. Selain itu, jangka waktu persediaan paling baik adalah PT Holcim Indonesia, hal ini menunjukkan bahwa PT Holcim Indonesia Tbk meminimalkan laba sehingga persediaan lebih cepat berputar. Untuk rasio perputaran modal kerja, PT Holcim Indonesia Tbk memiliki hasil yang paling tinggi dibandingkan dengan PT Indocement Tunggal Prakarsa Tbk dan PT Semen Gresik (Persero) Tbk, hal ini menunjukkan bahwa semakin cepat dana yang diinvestasikan dalam modal kerja kembali menjadi kas, sehingga keuntungan perusahaan dapat lebih cepat diterima, dan sebaliknya. Selain itu, PT Semen Gresik (Persero) Tbk memiliki rasio perputaran aktiva tetap yang paling tinggi, hal ini menunjukkan tingkat efektivitas penggunaan aktiva tetap dalam mendukung kegiatan penjualan baik.

Untuk rasio perputaran total aktiva, PT Semen Gresik (Persero) Tbk paling tinggi. Hal ini menunjukkan bahwa terjadi peningkatan penjualan. Selain itu, PT Holcim Indonesia Tbk memiliki margin laba atas penjualan yang tinggi, hal ini menunjukkan bahwa kinerja dalam menghasilkan margin laba atas penjualan baik. Untuk tingkat pengembalian atas total aktiva, PT Semen Gresik (Persero) memiliki tingkat pengembalian yang tinggi, hal ini menunjukkan peningkatan net profit margin dan perputaran total aktiva. Dan PT Semen Gresik (Persero) Tbk juga memiliki tingkat pengembangan atas ekuitas yang tinggi, hal ini menunjukkan profitabilitas perusahaan dalam pengembalian modal baik. PT Semen Gresik (Persero) memiliki rasio hutang yang rendah. Hal ini menunjukkan bahwa tidak semua aktiva dibiayai oleh hutang. Untuk PT Holcim Indonesia Tbk memiliki siklus konversi kas paling pendek, hal ini menunjukkan bahwa kas yang diterima PT Holcim Indonesia Tbk lebih baik dibandingkan dengan PT Indocement Tunggal Prakarsa Tbk dan PT Semen Gresik (Persero) Tbk.

\section{Perbandingan Rasio Modal Kerja Tiga Perusahaan Semen Tahun 2007}

Tabel 5 Rasio-Rasio Keuangan Tiga Perusahaan Semen Tahun 2007

\begin{tabular}{lllc}
\hline \multicolumn{1}{c}{ Financial Ratio 2007 } & \multicolumn{1}{c}{$\begin{array}{c}\text { PT Indocement } \\
\text { Tunggal }\end{array}$} & \multicolumn{1}{c}{ PT Semen Gresik } & $\begin{array}{c}\text { PT Holcim } \\
\text { Indonesia } \\
\text { Tbk }\end{array}$ \\
\hline Rasio lancar & Prakarsa Tbk & (PERSERO) Tbk & $114,93 \%$ \\
Rasio cepat & $288,64 \%$ & $364,34 \%$ & $86,84 \%$ \\
Rasio kas & $160,76 \%$ & $291,87 \%$ & $37,36 \%$ \\
Rasio perputaran piutang & $39,51 \%$ & $203,29 \%$ & $7 \mathrm{kali}$ \\
Rasio rata - rata penagihan piutang & $10,36 \mathrm{kali}$ & $8,50 \mathrm{kali}$ & $51 \mathrm{hari}$ \\
Rasio perputaran sediaan & 34 hari & 42 hari & $5,84 \mathrm{kali}$ \\
Rasio rata - rata penagihan sediaan & $4,68 \mathrm{kali}$ & $5,40 \mathrm{kali}$ & $62 \mathrm{hari}$ \\
Rasio perputaran modal kerja & $77 \mathrm{hari}$ & $67 \mathrm{hari}$ & $20,08 \mathrm{kali}$ \\
Rasio perputaran aktiva tetap & $4,98 \mathrm{kali}$ & $2,51 \mathrm{kali}$ & $1,11 \mathrm{kali}$ \\
\hline
\end{tabular}


Tabel 5 Rasio-Rasio Keuangan Tiga Perusahaan Semen Tahun 2007 (lanjutan)

\begin{tabular}{|c|c|c|c|}
\hline Financial Ratio 2007 & $\begin{array}{c}\text { PT Indocement } \\
\text { Tunggal } \\
\text { Prakarsa Tbk }\end{array}$ & $\begin{array}{l}\text { PT Semen Gresik } \\
\text { (PERSERO) Tbk }\end{array}$ & $\begin{array}{c}\text { PT Holcim } \\
\text { Indonesia } \\
\text { Tbk }\end{array}$ \\
\hline Rasio perputaran total asset & 0,75 kali & $1,20 \mathrm{kali}$ & $0,58 \mathrm{kali}$ \\
\hline Rasio perputaran modal kerja bersih & 4,98 kali & 2,51 kali & 20,08 kali \\
\hline Rasio hutang & $31,33 \%$ & $21,09 \%$ & $54,48 \%$ \\
\hline Margin laba atas penjualan & $7,46 \%$ & $10,51 \%$ & $16,80 \%$ \\
\hline Tingkat pengembalian atas total aktiva & $9,76 \%$ & $20,85 \%$ & $9,43 \%$ \\
\hline Tingkat pengembalian atas ekuitas & $14,20 \%$ & $26,79 \%$ & $20,71 \%$ \\
\hline Siklus Konversi Kas & 71 hari & 50 hari & 13 hari \\
\hline Modal Kerja & 1.469.569.690.127 & 3.822.037.385 & 1.347 \\
\hline
\end{tabular}

Dari ketiga perusahaan semen tersebut menunjukkan bahwa PT Semen Gresik (Persero) Tbk memiliki rasio lancar paling tinggi dibandingkan dengan PT Indocement Tunggal Prakarsa Tbk dan PT Holcim Indonesia Tbk. Akan tetapi, ketiga perusahaan semen mampu untuk membayar hutang jangka pendek, karena rasio lancar di atas 100\%. Untuk rasio cepat, PT Semen Gresik (Persero) Tbk memiliki rasio cepat paling tinggi. Hal ini menunjukkan PT Semen Gresik (Persero) Tbk dalam keadaan likuid. Selain itu, PT Semen Gresik (Persero) Tbk memiliki rasio kas yang paling tinggi, hal ini menunjukkan bahwa jumlah uang tunai yang tersedia semakin besar, sehingga pada saat jatuh tempo pelunasan hutang tidak mengalami kesulitan. PT Indocement Tunggal Prakarsa Tbk memiliki rasio perputaran piutang yang paling tinggi dibandingkan dengan PT Semen Gresik (Persero) Tbk dan PT Holcim Indonesia Tbk, hal ini menunjukkan bahwa PT Indocement Tunggal Prakarsa Tbk memiliki penjualan paling tinggi dengan rata - rata penagihan piutang yang singkat.

Untuk rasio perputaran sediaan, PT Holcim Indonesia Tbk paling tinggi, hal ini menunjukkan bahwa dana yang diinvestasikan pada persediaan efektif menghasilkan laba. Selain itu, jangka waktu persediaan paling baik adalah PT Holcim Indonesia, hal ini menunjukkan bahwa PT Holcim Indonesia Tbk meminimalkan laba sehingga persediaan lebih cepat berputar. Untuk rasio perputaran modal kerja, PT Holcim Indonesia Tbk memiliki perputaran yang tinggi, hal ini menunjukkan bahwa semakin tinggi tingkat perputaran modal kerja maka semakin cepat dana yang diinvestasikan dalam modal kerja kembali menjadi kas, sehingga keuntungan perusahaan dapat lebih cepat diterima. Selain itu, PT Semen Gresik (Persero) Tbk memiliki rasio perputaran aktiva tetap yang paling tinggi, hal ini menunjukkan tingkat efektivitas penggunaan aktiva tetap dalam mendukung kegiatan penjualan baik.

Untuk rasio perputaran total aktiva, PT Semen Gresik (Persero) Tbk paling tinggi. Hal ini menunjukkan bahwa terjadi peningkatan penjualan. Selain itu, PT Holcim Indonesia Tbk memiliki margin laba atas penjualan yang tinggi, hal ini menunjukkan bahwa kinerja dalam menghasilkan margin laba atas penjualan baik. Untuk tingkat pengembalian atas total aktiva, PT Semen Gresik (Persero) memiliki tingkat pengembalian yang tinggi, hal ini menunjukkan peningkatan net profit margin dan perputaran total aktiva. Sedangkan PT Semen Gresik (PERSERO) Tbk memiliki tingkat pengembangan atas ekuitas yang tinggi, hal ini menunjukkan profitabilitas perusahaan dalam pengembalian modal baik. PT Holcim Indonesia Tbk memiliki tingkat perputaran modal kerja bersih yang tinggi, hal ini menunjukkan bahwa makin tinggi perputaran modal kerja, semakin kecil dana yang tertanam dalam modal kerja untuk mencapai penjualan tertentu yang telah ditetapkan.

PT Semen Gresik (Persero) memiliki rasio hutang yang rendah. Hal ini menunjukkan bahwa tidak semua aktiva dibiayai oleh hutang. Untuk PT Holcim Indonesia Tbk memiliki siklus konversi kas paling pendek, hal ini menunjukkan semakin pendek siklus konversi kas maka akan semakin baik karena semakin sedikit kas yang digunakan untuk membiayai aktiva dan semakin efektif suatu perusahaan dalam menjalankan perputaran hutang perusahaan tersebut. 


\section{Perbandingan Rasio Modal Kerja Tiga Perusahaan Semen Tahun 2008}

Tabel 6 Rasio-Rasio Keuangan Tiga Perusahaan Semen Tahun 2008

\begin{tabular}{llll}
\hline \multicolumn{1}{c}{ Financial Ratio 2008 } & $\begin{array}{c}\text { PT Indocement Tunggal } \\
\text { Prakarsa Tbk }\end{array}$ & $\begin{array}{c}\text { PT Semen Gresik } \\
\text { (PERSERO) Tbk }\end{array}$ & $\begin{array}{c}\text { PT Holcim } \\
\text { Indonesia Tbk }\end{array}$ \\
\hline Rasio lancar & $178,57 \%$ & $338,58 \%$ & $92,84 \%$ \\
Rasio cepat & $100,62 \%$ & $263,03 \%$ & $69,78 \%$ \\
Rasio kas & $40,65 \%$ & $183,37 \%$ & $33,53 \%$ \\
Rasio perputaran piutang & $11,38 \mathrm{kali}$ & $9,23 \mathrm{kali}$ & $7 \mathrm{kali}$ \\
Rasio rata - rata penagihan piutang & 31 hari & 39 hari & 51 hari \\
Rasio perputaran sediaan & $5 \mathrm{kali}$ & $5,22 \mathrm{kali}$ & $5,63 \mathrm{kali}$ \\
Rasio rata - rata penagihan sediaan & 79 hari & 69 hari & 64 hari \\
Rasio perputaran modal kerja & $6,40 \mathrm{kali}$ & $2,45 \mathrm{kali}$ & $(32,63) \mathrm{kali}$ \\
Rasio perputaran aktiva tetap & $1,29 \mathrm{kali}$ & $3,82 \mathrm{kali}$ & $1,05 \mathrm{kali}$ \\
Rasio perputaran total asset & $0,92 \mathrm{kali}$ & $1,28 \mathrm{kali}$ & $0,54 \mathrm{kali}$ \\
Rasio perputaran modal kerja bersih & $6,4 \mathrm{kali}$ & $2,45 \mathrm{kali}$ & $(32,63) \mathrm{kali}$ \\
Rasio hutang & $24,69 \%$ & $22,91 \%$ & $60,23 \%$ \\
Margin laba atas penjualan & $11,84 \%$ & $12,10 \%$ & $8,85 \%$ \\
Tingkat pengembalian atas total aktiva & $15,47 \%$ & $23,80 \%$ & $4,93 \%$ \\
Tingkat pengembalian atas ekuitas & $20,54 \%$ & $21,27 \%$ & $12,38 \%$ \\
Siklus Konversi Kas & 64 hari & 44 hari & 10 hari \\
Modal Kerja & $1,527,391,307,330$ & $4,991,322,216$ & $(771)$ \\
\hline
\end{tabular}

Dari ketiga perusahaan semen tersebut menunjukkan bahwa PT Semen Gresik (Persero) Tbk memiliki rasio lancar paling tinggi dibandingkan dengan PT Indocement Tunggal Prakarsa Tbk dan PT Holcim Indonesia Tbk. Hal ini menunjukkan perusahaan semen mampu untuk membayar hutang jangka pendek, karena rasio lancar di atas 300\%. Untuk rasio cepat, PT Semen Gresik (Persero) Tbk memiliki rasio cepat paling tinggi. Hal ini menunjukkan PT Semen Gresik (Persero) Tbk dalam keadaan likuid. Selain itu, PT Semen Gresik (Persero) Tbk memiliki rasio kas yang paling tinggi, hal ini menunjukkan bahwa jumlah uang tunai yang tersedia semakin besar, sehingga pada saat jatuh tempo pelunasan hutang tidak mengalami kesulitan. PT Indocement Tunggal Prakarsa Tbk memiliki rasio perputaran piutang yang paling tinggi dibandingkan dengan PT Semen Gresik (Persero) Tbk dan PT Holcim Indonesia Tbk, hal ini menunjukkan bahwa PT Indocement Tunggal Prakarsa Tbk memiliki penjualan paling tinggi. Selain itu, PT Indocement Tunggal Prakarsa Tbk juga memiliki ratarata penagihan piutang yang paling singkat, hal ini menunjukkan bahwa dana dapat diterima lebih cepat karena konsumen membayar tepat waktu.

Untuk rasio perputaran sediaan, PT Holcim Indonesia Tbk paling tinggi, hal ini menunjukkan bahwa dana yang diinvestasikan pada persediaan efektif menghasilkan laba. Selain itu, jangka waktu persediaan paling baik adalah PT Holcim Indonesia, hal ini menunjukkan bahwa PT Holcim Indonesia Tbk meminimalkan laba sehingga persediaan lebih cepat berputar. Untuk rasio perputaran modal kerja, PT Indocement Tunggal Prakarsa Tbk dan PT Semen Gresik (Persero) Tbk memiliki hasil yang positif, sedangkan PT Holcim Indonesia Tbk memiliki hasil yang negatif, hal ini menunjukkan bahwa tingkat perputaran modal kerja positif maka semakin cepat dana yang diinvestasikan dalam modal kerja kembali menjadi kas, sehingga keuntungan perusahaan dapat lebih cepat diterima, dan sebaliknya. Selain itu, PT Semen Gresik (Persero) Tbk memiliki rasio perputaran aktiva tetap yang paling tinggi, hal ini menunjukkan tingkat efektivitas penggunaan aktiva tetap dalam mendukung kegiatan penjualan baik.

Untuk rasio perputaran total aktiva PT Semen Gresik (Persero) Tbk paling tinggi. Hal ini menunjukkan bahwa terjadi peningkatan penjualan. Dan PT Semen Gresik (Persero) Tbk memiliki margin laba atas penjualan yang tinggi, hal ini menunjukkan bahwa kinerja dalam menghasilkan margin laba atas penjualan baik. Untuk tingkat pengembalian atas total aktiva, PT Semen Gresik 
(Persero) memiliki tingkat pengembalian yang tinggi, hal ini menunjukkan peningkatan net profit margin dan perputaran total aktiva. Sedangkan PT Semen Gresik (Persero) Tbk memiliki tingkat pengembangan atas ekuitas yang tinggi, hal ini menunjukkan profitabilitas perusahaan dalam pengembalian modal baik. PT Indocement Tunggal Prakarsa Tbk memiliki tingkat perputaran modal kerja bersih yang tinggi, hal ini menunjukkan bahwa makin tinggi perputaran modal kerja, semakin kecil dana yang tertanam dalam modal kerja untuk mencapai penjualan tertentu yang telah ditetapkan.

PT Semen Gresik (Persero) memiliki rasio hutang yang rendah. Hal ini menunjukkan bahwa tidak semua aktiva dibiayai oleh hutang. Untuk PT Holcim Indonesia Tbk memiliki siklus konversi kas paling pendek, hal ini menunjukkan semakin pendek siklus konversi kas maka akan semakin baik karena semakin sedikit kas yang digunakan untuk membiayai aktiva dan semakin efektif suatu perusahaan dalam menjalankan perputaran hutang perusahaan tersebut.

\section{SIMPULAN DAN SARAN}

\section{Simpulan}

Simpulan yang didapat dari analisa pengelolaan modal kerja pada perusahaan industri semen, yaitu PT Indocement Tunggal Prakarsa Tbk memiliki rasio likuiditas tinggi sehingga perusahaan mampu membayar hutang jangka pendek dengan baik. Sedangkan secara keseluruhan rasio aktivitas PT Indocement Tunggal Prakarsa Tbk baik, tetapi perputaran persediaan dan jangka waktu persediaan di gudang lama. Untuk rasio solvabilitas rendah, sedangkan rasio profitabilitas baik, karena mengalami peningkatan dari tahun ke tahun.

PT Semen Gresik (Persero) Tbk memiliki rasio likuiditas tinggi sehingga kemampuan membayar hutang jangka pendek baik. Sedangkan secara keseluruhan rasio aktivitas perusahaan baik karena mengalami peningkatan. Untuk rasio solvabilitas rendah, sedangkan rasio profitabilitas baik karena mengalami peningkatan dari tahun ke tahun. PT Holcim Indonesia Tbk memiliki rasio likuiditas rendah sehingga perusahaan kurang mampu membayar hutang jangka pendeknya. Sedangkan secara keseluruhan rasio aktivitas kurang baik, disebabkan karena perusahaan memberikan kebijakan pada jangka waktu penagihan yang lama dengan syarat pengambilan kuantitas tertentu. Untuk rasio solvabilitas tinggi, sedangkan rasio profitabilitas PT Holcim Indonesia Tbk kurang baik karena NPM, ROA, dan ROE mengalami penurunan.

Hubungan antar rasio PT Indocement Tunggal Prakarsa Tbk dan PT Semen Gresik (Persero) Tbk pada perputaran piutang tinggi dengan jangka waktu singkat dan perputaran persediaan rendah dengan jangka waktu persediaan yang lama. Selain itu, perputaran modal kerja positif sehingga dapat dikatakan tingkat hutang perusahaan rendah. Dengan adanya siklus konversi kas yang pendek, maka semakin efektif dalam melaksanakan perputaran hutang. Hubungan rasio PT Holcim Indonesia Tbk pada perputaran piutang yang meningkat dengan jangka waktu yang lama dan perputaran persediaan meningkat dengan jangka waktu persediaan yang lama. Selain itu, perputaran modal kerja negatif sehingga dapat dikatakan tingkat hutang perusahaan tinggi. Untuk PT Holcim Indonesia Tbk memiliki siklus konversi kas paling pendek, hal ini menunjukkan semakin pendek siklus konversi kas maka akan semakin baik karena semakin sedikit kas yang digunakan untuk membiayai aktiva dan semakin efektif suatu perusahaan dalam menjalankan perputaran hutang perusahaan tersebut.

Pada tahun 2006, PT Semen Gresik (Persero) Tbk memiliki rasio likuiditas, profitabilitas dan rasio solvabilitas paling baik dibandingkan dengan perusahaan semen lainnya. Sedangkan PT Indocement Tunggal Prakarsa Tbk memiliki rasio likuiditas, rasio solvabilitas, rasio aktivitas yang baik dalam hal perputaran piutang dan jangka waktu penagihan piutang. Dan untuk PT Holcim Indonesia Tbk untuk rasio aktivitas baik dalam hal perputaran persediaan, jangka waktu persediaan. 
Dan PT Holcim Indonesia Tbk memiliki siklus konversi kas paling pendek, hal ini menunjukkan semakin baik karena semakin sedikit kas yang digunakan untuk membiayai aktiva dan semakin efektif suatu perusahaan dalam menjalankan perputaran hutang perusahaan tersebut.

Pada tahun 2007, PT Semen Gresik (Persero) Tbk memiliki rasio likuiditas, rasio solvabilitas, rasio profitabilitas dalam hal ROA, ROE paling baik. Sedangkan PT Indocement Tunggal Prakarsa Tbk untuk rasio likuiditas, rasio solvabilitas, rasio aktivitas baik dalam hal perputaran piutang dan jangka waktu penagihan piutang. Untuk PT Holcim Indonesia Tbk untuk rasio aktivitas baik dalam hal perputaran persediaan, jangka waktu persediaan, perputaran modal kerja dan rasio profitabilitas baik dalam hal margin laba atas penjualan. Dan PT Holcim Indonesia Tbk memiliki siklus konversi kas paling pendek, hal ini menunjukkan semakin baik karena semakin sedikit kas yang digunakan untuk membiayai aktiva dan semakin efektif suatu perusahaan dalam menjalankan perputaran hutang perusahaan tersebut.

Pada tahun 2008, PT Semen Gresik (Persero) Tbk memiliki rasio likuiditas, rasio solvabilitas, rasio profitabilitas paling baik. Sedangkan PT Indocement Tunggal Prakarsa Tbk untuk rasio likuiditas, rasio solvabilitas, rasio profitabilitas, rasio aktivitas baik dalam hal perputaran piutang, jangka waktu penagihan piutang, perputaran modal kerja. Untuk PT Holcim Indonesia Tbk untuk rasio aktivitas baik dalam hal perputaran persediaan, jangka waktu persediaan. Dan PT Holcim Indonesia Tbk memiliki siklus konversi kas paling pendek, hal ini menunjukkan semakin baik karena semakin sedikit kas yang digunakan untuk membiayai aktiva dan semakin efektif suatu perusahaan dalam menjalankan perputaran hutang perusahaan tersebut.

\section{Saran}

PT Indocement sebaiknya memperpendek konversi persediaan dan memperpanjang penangguhan hutang sehingga siklus konversi kas perusahaan bisa semakin pendek. Karena siklus konversi kas yang pendek, semakin baik berarti semakin sedikit kas yang digunakan untuk membiayai aktiva dan semakin efektif suatu perusahaan dalam menjalankan perputaran hutang perusahaan tersebut. PT Semen Gresik (PERSERO) Tbk sebaiknya memperpendek konversi persediaan, konversi piutang, dan memperpanjang penangguhan hutang sehingga siklus konversi kas semakin pendek. Karena siklus konversi kas yang pendek, semakin baik berarti semakin sedikit kas yang digunakan untuk membiayai aktiva. PT Holcim Indonesia Tbk sebaiknya mengurangi hutang jangka panjang dan meningkatkan aktiva untuk meningkatkan tingkat likuiditas agar perusahaan mampu membayar hutang-hutang jangka pendeknya tepat waktu.

\section{DAFTAR PUSTAKA}

Gitosudarmo, I. (2002). Manajemen keuangan. Yogyakarta: BPFE.

Harahap, S. S. (2001). Analisa kritis atas laporan keuangan. Jakarta: PT Raja Grafindo Persada.

Kasmir. (2010). Pengantar manajemen keuangan. Jakarta: Kencana.

Sutrisno. (2000). Manajemen keuangan: teori, konsep, dan aplikasi. Yogyakarta: Ekonisia, Fakultas Ekonomi UII. 